\title{
The influence of entrepreneur's characteristics on small manufacturing firm debt financing
}

\author{
Alenka Slavec, Igor Prodan ${ }^{* *}$
}

This paper investigates how entrepreneur's characteristics determine debt financing of small manufacturing firms. In particular, we investigate the influence of entrepreneurial self-efficacy, strong and weak social ties, gender, age, and entrepreneur's educational level on small firm debt financing. Research results show that small firm debt financing is determined by weak and strong social ties, entrepreneurial self-efficacy, and entrepreneur's educational.

Dieser Artikel erforscht, wie die Charakteristika der Unternehmer die Fremdfinanzierung von Herstellerfirmen beeinflussen. Im Besonderen erforschen wir den Einfluss des Selbstvertrauens des Unternehmers, von starken und schwachen soziale Beziehungen, des Geschlechts, des Alters, und des Bildungslevels des Unternehmers auf die Fremdfinanzierung kleiner Firmen. Die Forschungsergebnisse zeigen, dass die Fremdfinanzierung einer kleinen Firma von den sozialen Beziehungen, vom Selbstvertrauen und vom Bildungslevel des Unternehmers bestimmt ist.

Keywords: debt, financing, entrepreneurial self-efficacy, social ties, education level

\footnotetext{
Manuscript received: 13.08.2010, accepted 25.10.2011 (2 revisions)

** Alenka Slavec, Faculty of Economics, University if Ljubljana. Main research areas: Small business management, small firm financing \& psychology of entrepreneurs. Corresponding address: alenka.slavec@ef.uni-lj.si

Igor Prodan, Prof. Dr., Faculty of Economics, University if Ljubljana. Main research areas: Small business management \& innovation management.
} 


\section{Introduction}

Entrepreneurship has been increasingly considered as an important means for economic growth and innovation across regions and economies (e.g., Acs et al. 2008; Baycan-Levent/Nijkamp 2009; Cornett 2009). Entrepreneurship, the entrepreneurial process, and entrepreneurs themselves are at the center of policy discussions, incentives, and in-depth academic research. This increasing attention is motivated by various observations: SMEs account for the majority of firms in an economy (Beck/Demirguc-Kunt 2006; Hallberg 2000; McGibbon/Moutray 2009); in developed countries, a significant portion of economic growth rates can be attributed to high-expectation entrepreneurs (Valliere/Peterson 2009); and SMEs account for a significant share of employment (Coleman/Cohn 2000; Storey 1994a) as well as a substantial contribution to gross domestic product (Ayyagari et al. 2007; Coleman/Cohn 2000). However, since small firms are addressed as more informationally opaque (Flannery 1986; Liao et al. 2009; Sharpe 1990), they face greater constraints in accessing external financial sources, which might impede their ability to grow and develop (Beck/Demirguc-Kunt 2006; Hughes 1996).

As many researchers have observed (e.g., McMahon/Stanger 1995; Neubauer/Lank 1998; Romano et al. 2001), any study that attempts to explain the capital structure decision-making processes has to move beyond the use of publicly available information from databases or annual reports. Moreover, several researchers have shown that entrepreneurs themselves are important factors that influence performance, growth, and financing decisions in small firms (e.g., Coleman/Cohn 2000; Vos et al. 2007). In addition, MacMillan et al. (1985) studied criteria that were used by venture capitalists to evaluate new venture proposals and found that entrepreneur's qualities, entrepreneur's experiences, and entrepreneur's personality matter the most in funding decisions. In line with these argumentations, we make a further step into the investigation of the importance of the entrepreneur in debt financing of small firms. In doing so, we analyze how six entrepreneur's characteristics entrepreneurial self-efficacy, social networks (strong and weak ties), gender, age, and degree of education - influence debt financing of their small firms.

The remainder of this paper is organized as follows. First, we review the literature regarding entrepreneur's characteristics and their influence on debt financing. Based on the literature review we postulate our research hypotheses and develop a conceptual model of small firm financing. Second, we explain the methodology used for collecting data and developing the structural equation model (SEM). We continue with the results of our study derived from testing the proposed hypotheses. The last part of the paper discusses our findings and proposes implications for policy makers, entrepreneurs, and scholars. 


\section{Theory and hypotheses development}

Despite the awareness that a vast, effective, and innovative SME sector is crucial for the growth, development, and competitive position of an economy, there are still obstacles that constrain small firms' use of external financial sources. It is widely recognized that the availability of external financial sources for small firms is limited owing to their specific characteristics. Informational asymmetry and incomplete information between borrowers and lenders represent potential financing problems for small firms (Liao et al. 2009; Myers 1984; Sharpe 1990). Thus, due to informational opaqueness, providing financial resources to small firms is regarded as riskier than financing larger firms.

The reason lies in the uncertainty whether small firms are willing to and are able to pay their liabilities (Torre et al. 2008). Furthermore, the perceived moral hazard problems that can arise after credit has been granted (Berger/Udell 1998; Darrough/Stoughton 1986), and the adverse selection problem (Petersen/Rajan 1995; Stiglitz/Weiss 1981) make lending to small firms a risky activity. These informational problems occur because there is often no "hard" or verifiable information available; after all, small firms are not required to publish audited financial statements (Berger/Udell 1998; Coleman/Cohn 2000) and are unlikely to be monitored by rating agencies or the financial press (Ortiz-Molina/Penas 2008). The scarcity of public information together with the more informal and opaque status of small firms constrain their ability to attract investors.

Although the importance of small businesses has motivated a number of researchers to study the determinants of debt use of small firms, a review of the literature shows that the influence of some entrepreneur's characteristics on debt financing of small firms remain underexplored. Besides that, researchers have argued that small business loan performance is better predicted by the characteristics of business owners rather than the business itself (Mester 1997). Avery et al. (1998) also showed that lenders base their lending decisions on the creditworthiness of small business owners rather than on less reliable information on the business itself. Additionally, Ortiz-Molina and Penas (2008) stated that lenders base their credit decisions on entrepreneur's characteristics and ability, since it is difficult to distinguish firm finances from owner finances.

Because of the awareness of the crucial role that entrepreneurs play in small firm performance and considering the fact that lenders pay attention to the characteristics of entrepreneurs as well as their firms, it is necessary to investigate the influence of entrepreneur's characteristics on debt financing of small firms. In this study, we seek to advance the understanding of the influence of some underexplored entrepreneur's characteristics - entrepreneurial selfefficacy and strong and weak social ties - on small firm debt financing. In addition, we investigate the influence of entrepreneur's age, educational level, and gender on debt financing of small firms. 


\section{Entrepreneurial self-efficacy and debt financing}

The construct of self-efficacy originates in psychology and refers to an individual's cognitive judgment of one's capabilities to mobilize the motivation, cognitive resources, and courses of action needed to exercise control over events in their lives (Wood/Bandura 1989). Self-efficacy as a motivational construct has been shown to influence an individual's choice of activities, goal levels, persistence, and performance in a range of contexts (Zhao et al. 2005). The selfefficacy literature suggests that high self-confidence generally leads to high aspirations, persistence, and the achievement of goals (Bandura 1997; Gist 1987; Mone/Baker 1995; Mone et al. 1998).

In an entrepreneurial context, entrepreneurial self-efficacy is defined as an individual's confidence in his/her ability to succeed in entrepreneurial roles and tasks (Chen et al. 1998; Boyd/Vozikis 1994; Scherer et al. 1989). Entrepreneurial self-efficacy, or the way a person perceives his/her abilities and tendencies, plays an important role in the development of intensions to establish and manage a business. In addition, it affects one's belief regarding whether a certain goal can be attained (Boyd/Vozikis 1994). So, if a certain behavior, that is, an entrepreneurial role or task, is perceived to be beyond the ability of the (potential) entrepreneur, he or she will not act (Boyd/Vozikis 1994, Wood/Bandura 1989).

Despite its fairly stable nature, entrepreneurial self-efficacy is not immutable; rather, entrepreneurs can derive, modify, and enhance their entrepreneurial selfefficacy in their continuous interaction with their environment (Chen et al. 1998). Although it has been found that entrepreneurial self-efficacy has a positive influence on opportunity recognition (Ozgen/Baron 2007), new venture performance (Hmieleski/Corbett 2008), and entrepreneurial intentions (Boyd/Vozikis 1994; Krueger et al. 2000; Prodan 2007), there is a gap in the literature regarding the influence of entrepreneurial self-efficacy on debt financing of small firms.

Considering these results from different research fields, we continue with some other findings that will enhance our understanding of how entrepreneurial selfefficacy affects debt financing. An important basis for our research on the influence of entrepreneurial self-efficacy on debt financing of small firms is that entrepreneurial self-efficacy has been found to be a key antecedent for entrepreneurial choice (Boyd/Vozikis 1994; Krueger 1993). Therefore, from the lender's point of view, entrepreneurs who show strong beliefs in their capabilities to achieve their goals in the context of entrepreneurial activities and roles will presumably be assessed as better borrowers than less self-efficacious entrepreneurs.

Lenders can observe an entrepreneur's self-efficacy from several perspectives. From one point of view, an entrepreneur can demonstrate his/her confidence in 
his/her abilities to the lender when proposing an accurate and detailed business plan that is handed to the prospective lender. For an illustration, we can draw parallels between an entrepreneurial self-efficacy item such as "I am able to control costs" and the accurate evaluation of actual costs that the firm will experience. If the lender assesses that predicted costs in a business plan are reasonable, they get a positive opinion of the entrepreneur's confidence in his/her abilities and hence the level of the entrepreneur's self-efficacy. The reason for this is that in this way the entrepreneur shows that he/she is aware of what to expect and knows his/her limits in abilities.

In later stages, the lender can observe an entrepreneur's level of entrepreneurial self-efficacy by evaluating if the expected results written in the business plan have been attained or not. So, items such as "I am able to set and attain profit goals" or "I am able to expand the business" can be verified by field evidencedid the firm really experience the profit goals that were expected and did the firm grow? Thus, if the entrepreneur is not capable of articulating a business plan that would meet the requirements of the bankers or investors and has a lot of shortcomings and wrong suppositions and expectations of business outcomes, it might be that he/she is low in his/her entrepreneurial self-efficacy and lenders would not be willing to finance such entrepreneurs.

This argumentation is consistent with the conceptualization theory on entrepreneurial self-efficacy since it proposes entrepreneurial self-efficacy as an important explanatory variable in determining both the strength of entrepreneurial intentions and the likelihood that those intentions will result in entrepreneurial actions (Boyd/Vozikis 1994). Those entrepreneurs with high entrepreneurial self-efficacy feel more competent to deal with that reality than those with low entrepreneurial self-efficacy (Chen et al. 1998).

A second view from which lenders can observe an entrepreneur's self-efficacy deals with the relationship between the lender and the borrower. It has been shown that having a close relationship with the lender increases the chance of getting a loan (e.g., Berger/Udell 2006; Petersen/Rajan 2002, Cavalluzzo/Cavalluzzo 1998). The reason is that the asymmetry of information decreases and the lender is more confident about timely repayments. Through this closer relationship, the lender, among other things, realizes an entrepreneur's intentions, abilities, and confidence in his/her abilities to perform tasks that will lead to good firm performance. And if an entrepreneur is confident that he/she will "attain market share goals" and "establish position in the product/service market," then he/she will show this confidence outwardly.

It also appears that lenders prefer to finance entrepreneurial activities of more self-efficacious entrepreneurs because of the positive influence of self-efficacy on goal achievement (Bandura 1977) and new venture performance (Hmieleski/Corbett 2008). In other words, entrepreneurs with high self-efficacy 
will be more likely to achieve their stated goals, and their firms will be more likely to perform better than the firms of less self-efficacious entrepreneurs.

Building on these considerations, we also propose a positive demand-side influence of entrepreneurial self-efficacy on debt financing by arguing that more self-efficacious entrepreneurs will be more prone to apply for debt financing. It is their confidence in goal achievements and personal business capabilities that will lead them to the acquirement of external financial resources to achieve stated goals. A lower entrepreneurial self-efficacy might be resembled also by the category of "discouraged borrowers"-firms that need outside finance but possibly view their prospects of getting a loan as poor and hence might not approach the borrower (Storey 1994b). So, it might be the case that more confident borrowers apply for loans more than borrowers that have lower confidence in their abilities.

Our contemplation is further strengthened by arguments from Barton and Matthews (1989) and Chaganti et al. (1995) who state that a firm's capital structure is affected, among other factors, by the entrepreneur's goals. Goals, self-efficacy, and communicated vision have direct effects on venture growth (Baum/Locke 2004). Besides that, a positive influence of growth opportunities on small firm debt financing has been found by Michaelas et al. (1999). Nevertheless, Beck et al. (2005) showed that debt financing also affects firm growth. Thus, if we consider the abovementioned fact that debt financing enhances firm growth (Beck et al. 2005) and that self-efficacy, as well, has a direct effect on venture growth (Baum/Locke 2004), we can assume that higher self-efficacy will positively affect debt financing of small firms.

In summary, higher entrepreneurial self-efficacy will foster lenders' confidence in entrepreneurs' capabilities for paying their liabilities back. Thus, lenders will be more prone to lend to highly self-efficacious entrepreneurs than to those who do not show a strong belief in their ability to succeed in entrepreneurial activities. On the other hand, more self-efficacious entrepreneurs will search for debt financing more than their less self-efficacious counterparts do because they believe in their capabilities to achieve their goals. Consequently, entrepreneurs with high entrepreneurial self-efficacy will obtain more debt financing. On the basis of this explanation, we postulate our first hypothesis as follows:

Hypothesis 1: Higher entrepreneurial self-efficacy is positively related to debt financing of small firms.

\section{Strong social ties and debt financing}

Strong social ties refer to entrepreneur's family, parents, and friends who see each other frequently and have intimate, reciprocal, and emotionally intensive contacts (Granovetter 1973). Strong social ties provide the members of the 
strong-tie network with profound moral support, reassurance, and advice and are a source of information for the entrepreneur (Birley 1985).

Strong ties are important factors for a start-up team seeking to gather enough seed capital (Hutchinson 1995; Waldinger et al. 1990), equipment, space, and money (Birley 1985) to establish a business. In addition, Birley (1985) found that the main sources of help in assembling the resources of raw materials, supplies, equipment, space, employees, and orders were the informal contacts of family, friends, and colleagues. Aldrich et al. (1987) argued that preexisting contacts, especially with family and friends, provide resources during the formation of a business. Besides that, Carter and Van Auken (2005) found that owners who see themselves as having limited financial ability are more likely to use private owner financing techniques that tend to squeeze all available funds from the owner and those close to him/her. Therefore, at least in the initial stage of the lifecycle of the firm, the strong-ties network reduces the need to access formal bank landing (Le/Nguyen 2009). Consistent with these considerations we postulate a negative effect of strong ties on debt financing.

The hypothesized negative relationship between strong social ties and debt financing is further strengthened by the Pecking Order theory (Myers 1984; Myers/Majluf 1984). By this theory there exists a financing hierarchy by which firms prefer internal finance to external finance and when external finance is needed, debt is preferred to equity. The rationale behind this model is that raising external finance is more expensive than raising internal finance (from strong social ties) because external financiers (representatives of weak social ties) have less information about the firm and its vision/prospects than insiders or representatives of an entrepreneur's strong-tie network do; therefore, external financiers demand higher costs for their investments. In addition to that, internal financial sources are more flexible in terms of repayment.

All things concerned, it is also the supply-side perspective with its higher cost of external financial sources and requests for timely repayments that could divert small firm owners to borrow from them if, on the other hand, there is the possibility of borrowing from strong-ties representatives. In other words, debt financing will only be used when there is an inadequate amount of internal funding available, and equity will only be used as a last resort (Heyman et al. 2008).

On the other hand, we can assume that lenders would be more willing to lend to entrepreneurs with large networks of strong social ties (Wu et al. 2007) since these ties will support the entrepreneur when he or she is confronted with repayment difficulties. Despite the presumed positive effect of strong social ties on small firm financing exposed by the supply side, we believe that the opposite effect from the demand side will prevail. That is, entrepreneurs with a large strong-tie network will not search for external financial sources. It is also reasonable to assume that lenders do not dispose with actual information of the 
quality and size of the entrepreneur's strong-tie network, which is another reason why the demand-side effect would prevail. On the basis of this discussion, we postulate our second hypothesis as follows:

Hypothesis 2: The extent of strong social ties is negatively related to debt financing of small firms.

\section{Weak social ties and debt financing}

An entrepreneur's network of weak ties consists of contacts with banks, accountants, lawyers (Birley 1985), acquaintances, business partners, former employees, and former co-workers (Bruderl/Preisendorfer 1998). Thus, weak ties are represented by contacts with people that do not see each other as frequently as strong-tie representatives and do not have intimate relationships (Granovetter 1973).

There have been many studies on the importance of an individual's network in accessing new information, especially the ways in which weak ties are particularly likely to provide unique and heterogeneous information (Granovetter 1973) and resources. Since weak social ties have been identified as important for individuals and entrepreneurs, the literature review shows that the influence of relationships with bankers and institutional lenders on the financing of firms has brought consistent results, whereas the influence of weak social ties in general (not only with bankers) on debt financing remains a relatively underexplored research area. Thus, in this section, we summarize different findings about the importance of weak ties in obtaining new information as well as the importance of weak ties in obtaining financing. These findings will motivate us in proposing the research hypothesis about the influence of weak ties on debt financing of small firms.

Burt (2001) stressed the importance of an individual's connections to other groups that give them an advantage with respect to information access; namely, the individual reaches a higher volume of information because he or she reaches more people indirectly. Singh (1998) pointed out another advantage of an individual's network - the network can provide access to knowledge not available to the individual. Since new firms suffer from newness and lack of legitimacy within the market, entrepreneurs use social networks to establish legitimacy (Johannisson 2000) and to build their reputation and credibility. Butler and Hansen (1991) examined the development and use of networks in establishing a business and observed that firm growth and the consequent need for strategic alliances foster the establishment and formation of more formal and professional contacts.

Thus, weak ties are an important channel for widening a new firm's circle of customers, suppliers, and profitable investment projects. Moreover, wider networks are essential for firm growth because they provide access to resources 
held by other actors within the network (Neergaard/Madsen 2004; Shaw/Conway 2000) and provide information about access to physical and financial resources (Johannisson 2000).

Furthermore, Petersen and Rajan $(1994,1995)$ argue that specifically for a small firm, social networks are of vital importance for broadening the availability of financial sources. In particular, members of business networks are thought to have greater access to financial resources as well as information.

A wide range of studies also found that building longer and closer relations with providers of finance, institutional creditors, and bankers increases the availability of funds (e.g., Beck et al. 2007; Berger/Udell 1995; Cavalluzzo/Cavalluzzo 1998; Cole 2008; Johannisson 2000; Petersen/Rajan 1994). On the basis of these observations, we propose the following hypothesis:

Hypothesis 3: The extent of weak social ties is positively related to small firm debt financing.

\section{Gender and debt financing}

Although women-owned firms still constitute a minority of small firms, their numbers have been growing rapidly (Coleman 2007). However, the gender of the major decision maker may also influence the capital structure of a small firm as well as the availability of financial sources (Cassar 2004) because the literature regarding the influence of the entrepreneur's gender on financing has revealed some discrimination against providing financial resources to womenowned businesses (e.g., Aaronson et al. 2004; Cavalluzzo et al. 2002; Coleman 2000).

Explanations may include the perception of women as more risk-averse (Chaganti 1986; Olson/Currie 1992; Scherr et al. 1993) and less willing to engage in larger businesses (Morris et al. 2006) because they have to balance between work and family more than men, which results in women becoming involved in smaller firms (Caputo/Dolinsky 1998). Coleman (2000) found evidence of credit discrimination because women were more frequently ask to pledge collateral and were charged higher interest rates. Finally, the denial rate for loan applicants is higher for women than for men (Cavalluzzo et al. 2002).

Some scholars have asserted that women-owned firms do not require as many external financial resources as men-owned firms because they are smaller and more likely to be concentrated in less asset-intensive businesses, such as personal services (Chaganti 1986). On the basis of this discussion, we formulate our next hypothesis:

Hypothesis 4: Women entrepreneurs use less debt financing than men entrepreneurs. 


\section{Entrepreneur's age and debt financing}

Regarding entrepreneur's age, the small business finance literature suggests a negative influence of entrepreneur's age from both - the demand and supply side. From the demand-side perspective, older entrepreneurs tend to be less willing to invest additional finances into their firms (Romano et al. 2001); thus, they would also use less debt (Van der Wijst 1989). In addition, older entrepreneurs may have accumulated enough wealth during their lives so that they eventually require less external financial sources. This is consistent with Vos et al. (2007), who argue that younger entrepreneurs more actively use external financing, while older ones are less likely to seek or use external financing.

Consistent with the demand side, also from the supply-side point of view, older entrepreneurs from small firms will be associated with less debt financing. From the lender's point of view, older entrepreneurs may be associated with riskier loans as their incentives to maintain a clean credit record decrease as they approach retirement (Ortiz-Molina/Penas 2008). So, lenders prefer not to lend to older entrepreneurs. Furthermore, the retirement of the current owner may force the lender to negotiate with a successor of unknown creditworthiness (OrtizMolina/Penas 2008).

Since the literature review suggests a negative relation between entrepreneur's age and debt financing, we also assume that older entrepreneurs will use less debt. Therefore, following hypothesis is postulated as follows:

Hypothesis 5: Entrepreneur's age is negatively related to small firm debt financing.

\section{Educational level and debt financing}

Entrepreneur's educational level may provide a signal of better human capital (Cassar 2004), and thus, lenders may perceive more educated entrepreneurs as less risky. For this reason, lenders will be more prone to provide financial resources to the more educated ones.

Accordingly, Coleman and Cohn (2000) found some evidence of education being positively related to external loans. Bates (1990) analyzed the influence of entrepreneur's characteristics on small business longevity and argued that entrepreneur's educational background is a major determinant of the financial capital structure of small business startups and is the strongest human capital variable for identifying business continuance. Moreover, entrepreneurs with higher educational levels usually tend to be more liable for firm growth because many scholars found evidence of a positive effect of educational level on firm growth (Almus/Nerlinger 1999; Jo/Lee 1996; Johnson et al. 1999; Roberts 1991; Van de Ven et al. 1984; Wilbon 2000). 
Since external financial sources have a positive effect on firm growth (e.g., Beck et al. 2005) and higher education has a positive influence on firm growth, we can also assume that higher educational levels may have a positive influence on external financing of small firms. On the basis of this discussion, we propose the following hypothesis:

Hypothesis 6: Higher educational levels predict more debt financing of small firms.

Taking into account existing findings in the financial, entrepreneurial, sociological, and psychological literature, we propose a unique model of small firm debt financing based on the proposed research hypotheses (see Figure 1).

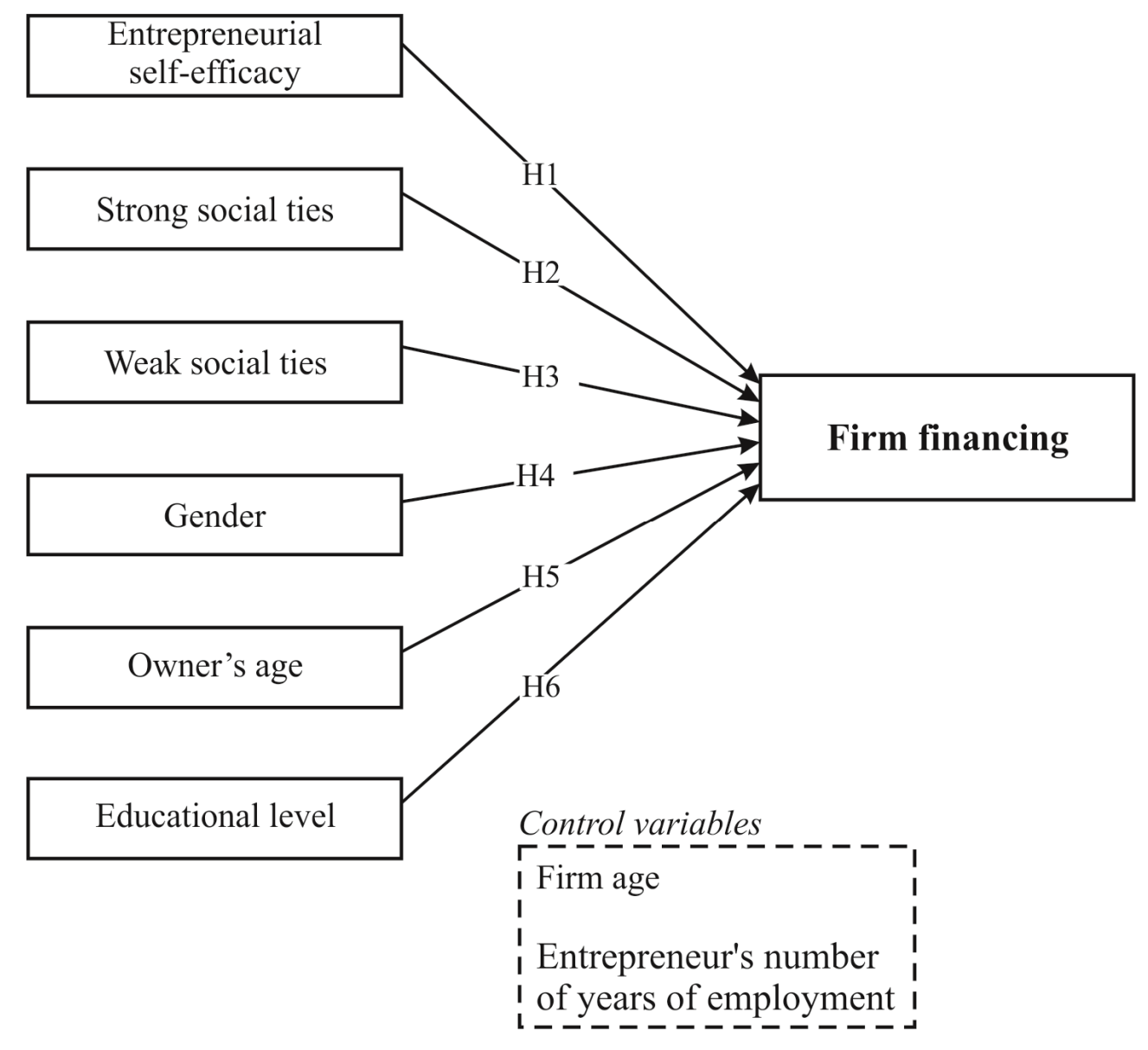

\section{Methods}

We now discuss the methods in terms of measurement instruments, sampling, and data analysis.

Questionnaire data were collected from entrepreneurs of randomly selected manufacturing firms from Slovenia with up to 49 employees (only small firms were included; firms with less than 5 employees were excluded from the survey sample since many of them are dormant firms). Dillman's (2000) tailored design method for questionnaire development and administration was followed. This is a set of procedures for conducting successful self-administered surveys that 
produce both high-quality information and high response rates. The survey was sent by mail. Approximately one week after the survey was mailed, a personalized thank you e-mail was sent to express appreciation to the respondents if they had returned the questionnaire, and to urge a response from those who had not responded yet. If the survey had not been returned in three weeks, a personalized e-mail reminder was sent.

A total of 525 responses were received out of 2,200 mailed surveys. Furthermore, for all responses, the corresponding financial data were obtained from firms' balance sheets and income statements. Firms' balance sheets and income statements were obtained from the GVIN database. We were able to obtain firms' balance sheets and income statements from the GVIN database because respondents exposed their identity to us when they returned the questionnaire. Twenty-eight responses for which we failed to obtain the corresponding financial data were excluded. In total, we got 497 usable responses.

Exploratory factor analysis and reliability analysis were conducted using the SPSS statistical software. Structural equation modeling using EQS Multivariate Software version 6.1 was applied for confirmatory factor analysis and testing of the proposed structural models. Structural equation modeling was used because of its ability to incorporate multiple measures for each concept (Hair et al. 2010). A full structural equation and measurement model was used to assess the theoretical model.

Structural equation modeling is a statistical methodology that takes a confirmatory (i.e., hypothesis-testing) approach to the analysis of a structural theory bearing on some phenomenon (Byrne 2006). Typically, this theory represents "causal" processes that generate observations on multiple variables (Bentler 1988). The general structural equation model can be decomposited into two sub-models: a measurement model and a structural model. The measurement model defines relations between the observed and unobserved variables. It represents the confirmatory factor analysis model in that it specifies the pattern by which each measure (i.e. observed variable) loads on a particular factor. So, it enables us to test how well the measured variables represent the factors (Hair et al. 2010). In contrast, the structural model defines relationships among unobserved or latent variables (i.e. the factors under study in the measurement model). Accordingly, it specifies the manner in which particular latent variables directly or indirectly influence changes in the values of certain other latent variables in the model (Byrne 2006).

Our model was tested in a simultaneous analysis of the entire system of variables to determine the extent to which it is consistent with the data. If the goodness of fit is adequate, the model argues for the plausibility of postulated 
relations among variables; if it is inadequate, the tenability of such relations is rejected (Byrne 2006).

The goodness of fit can be assessed in many ways. Practitioners are generally advised to examine multiple fit criteria rather than rely on a single statistic (Breckler 1990). The use of multiple indices assures readers that authors have not simply picked a supportive index (Shook, et al. 2004). Thus, in this study, the fit of the model was assessed with multiple indices (NFI, NNFI, CFI, IFI, GFI, SRMR, and RMSEA). Since a small amount of non-normality was found in the data, the ERLS estimation method was used (Sharma et al. 1989). The research was carried out in 2009.

In this research, the dependent variable firm financing was measured with two items: short-term debt and long-term debt (the data for the corresponding items were retrieved from firm balance sheets). The entrepreneurial self-efficacy was measured with ten items. Respondents were asked to assess their perceived abilities to complete the following entrepreneurial tasks on a 5-point scale ranging from "1-completely unsure" to "5-completely sure": take responsibility for new ideas and decisions, take calculated risks, set and attain sales goals, set and attain profit goals, perform financial analysis, make decisions under uncertainty, make a strategic plan, find new markets, expand business, and conduct market analysis. This list was adapted from Chen et al.'s (1998) study and previously used by several scholars (e.g., Prodan/Drnovsek 2010). Exploratory factor analysis extracted one factor $(\mathrm{N}=497$; Kaiser-Meyer-Olkin measure of sampling adequacy: 0.90; Bartlett's test of sphericity: approx. chisquared of 1997.345; 45 df; sig. 0.000; Variance explained: 43.1\%; all factors loading above 0.5). Entrepreneurial self-efficacy was entered as a latent construct into the model of the influence of entrepreneur characteristics on debt financing of small firms.

Strong social ties were measured as the number of family members and friends with whom the respondents talked about important matters in the last three months (number of family members and friends were measured separately and later added together). Weak social ties were measured as the number of coworkers, business partners, and counselors with whom the respondents talked about important matters in the last three months (number of co-workers, business partners, and counselors were measured separately and later added together). Both measures were adapted from Greve (1995).

Gender was measured with a dichotomous variable (1-Male; 0-Female). Entrepreneur's age was measured in years. Educational level was measured with a dichotomous variable that indicated whether the respondent had finished more than secondary school or not. Those who had finished elementary, vocational, or secondary school were coded as 0 ; those who had finished professional college, university, or higher education were coded as 1. Control variables were also 
operationalized and included: firm age (in years) and entrepreneur's number of years of employment (in years).

The descriptive statistics and correlation matrix of the measurement items are presented in Table 1. Approximately $82 \%$ of all entrepreneurs that were included in the sample were male. The average respondent was 46.6 years old and has had a total of 23.7 years of professional experience. The average firm age was of 11 years. The sample distribution is comparable to the population. 
The influence of entrepreneur's characteristics

Table 1: Measurement items' descriptive statistics and correlation matrix

\begin{tabular}{|c|c|c|c|c|c|c|c|c|c|}
\hline$E$ & & & & & & & & & \\
\hline$\stackrel{6}{g}$ & & & & & & & & & \\
\hline$\stackrel{\sqrt{2}}{=}$ & & & & & & & & & \\
\hline త્ & & & & & & & & & \\
\hline$\stackrel{\cong}{=}$ & & & & & & & & & \\
\hline$\widehat{\Xi}$ & & & & & & & & & \\
\hline$\Xi$ & & & & & & & & & \\
\hline$\stackrel{\varrho}{\varrho}$ & & & & & & & & & \\
\hline$\widehat{a}$ & & & & & & & & & - \\
\hline$\widehat{\infty}$ & & & & & & & & - & $\because$ \\
\hline$E$ & & & & & & & - & $\vec{b}$ & $\stackrel{\infty}{+}$ \\
\hline$\underline{e}$ & & & & & & - & ? & m. & ๆे \\
\hline (c) & & & & & - & f. & fீ. & $q$ & $n$ \\
\hline 过 & & & & - & กิ & $\stackrel{n}{n}$ & f. & q. & f \\
\hline$\widehat{c}$ & & & - & $\stackrel{n}{n}$ & $F$ & ભે & ๆ & ๆ. & ले \\
\hline$\widehat{\Omega}$ & & - & $\bar{n}$ & $\hat{n}$ & ले & $\widetilde{ָ}$ & ㅇ․ & $\ddot{m}$ & ले \\
\hline 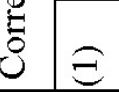 & - & $\bar{m}$ & J & $\approx$ & 导 & $n$ & $\stackrel{\varphi}{n}$ & q & 抽 \\
\hline 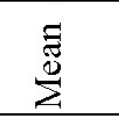 & 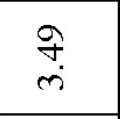 & $\stackrel{\rightleftharpoons}{\rightleftharpoons}$ & مे & $\stackrel{m}{\stackrel{m}{n}}$ & $\hat{a}$ & $\stackrel{n}{n}$ & $\begin{array}{l}\vec{\infty} \\
\dot{m}\end{array}$ & $\stackrel{\infty}{\infty}$ & $\underset{\dot{m}}{\vec{m}}$ \\
\hline 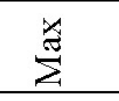 & $n$ & in & in & $n$ & in & $n$ & in & in & in \\
\hline$\stackrel{\Xi}{\Sigma}$ & - & - & - & - & - & - & $N$ & - & - \\
\hline 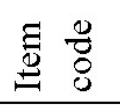 & 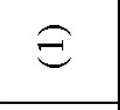 & $\widehat{d}$ & (్) & Ð & $\sqrt{c}$ & (e) & $E$ & $\widehat{\infty}$ & $\widehat{\sigma}$ \\
\hline Е & 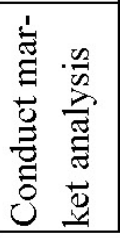 & 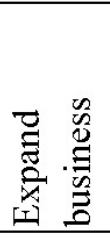 & 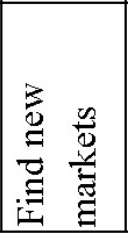 & 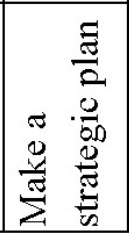 & 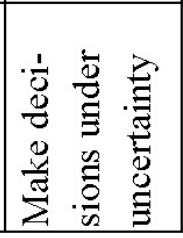 & 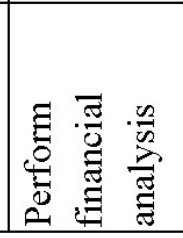 & 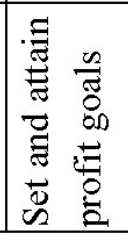 & 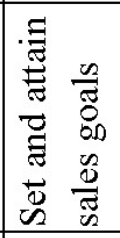 & 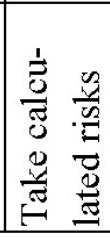 \\
\hline 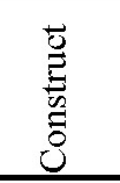 & \multicolumn{7}{|c|}{ 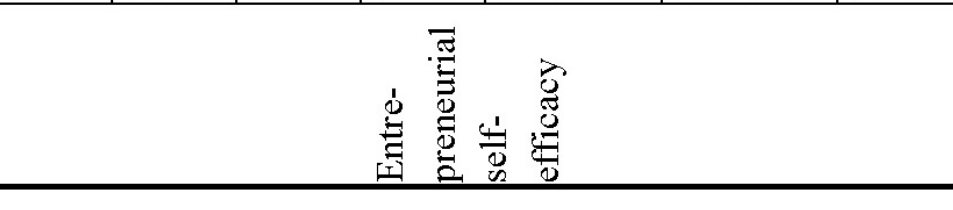 } & & \\
\hline
\end{tabular}




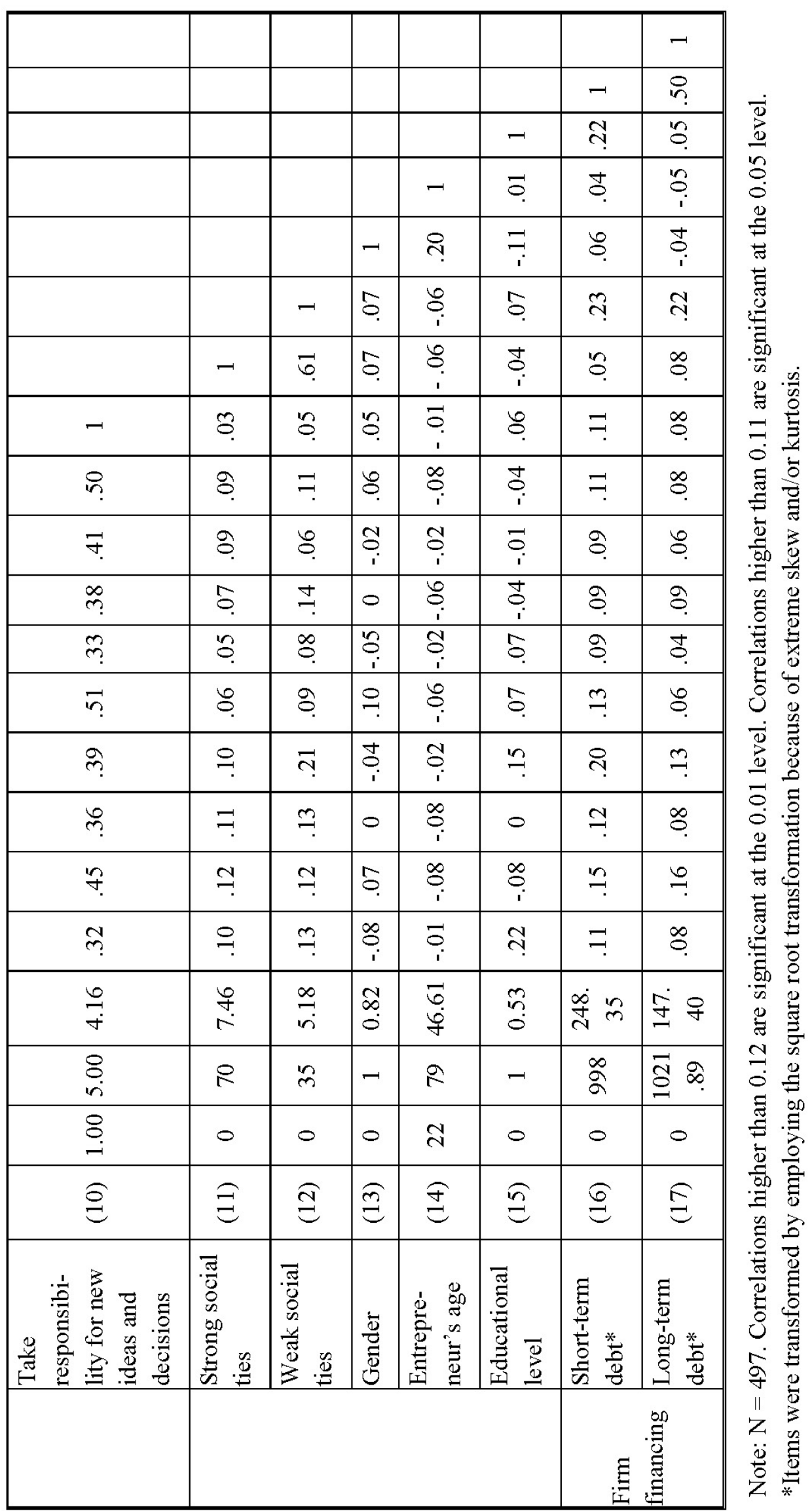




\section{Findings}

The structural equation method (SEM) was applied for the model test. The goodness of fit indices indicated a good model fit (NFI $=0.91$; NNFI $=0.90$; $\mathrm{CFI}=0.93$; IFI $=0.93 ; \mathrm{GFI}=0.90 ; \mathrm{SRMR}=0.07$; and $\mathrm{RMSEA}=0.07$ ). Although the chi-squared statistic is significant for $p<0.01$, this was not a major consideration because this statistic is very sensitive to sample size (Bentler/Bonett 1980; Hair et al. 1998). A discussion of the results of the hypotheses related to the model of the influence of entrepreneur characteristics on debt financing of small firms is presented in the following paragraph. The structural equations with standardized coefficients are shown in Table 2.

Table 2: Structural equations for the model

\begin{tabular}{||l|r|}
\hline Independent variables & $\begin{array}{l}\text { Firm } \\
\text { financing }\end{array}$ \\
\hline Entrepreneurial self-efficacy & $.12^{*}$ \\
\hline Strong social ties & $-.13^{*}$ \\
\hline Weak social ties & $.29^{*}$ \\
\hline Gender & .05 \\
\hline Entrepreneur's age & .07 \\
\hline Educational level & $.19^{*}$ \\
\hline Control variables & -.04 \\
\hline Firm age & -.02 \\
\hline $\begin{array}{l}\text { Entrepreneur's number of years of } \\
\text { employment }\end{array}$ & .89 \\
\hline Error & .21 \\
\hline R-squared & \\
\hline
\end{tabular}

Note: $*$ Sig. $<0.05$

Hypothesis 1 predicted that entrepreneurial self-efficacy would be positively related to debt financing. Empirical results support hypothesis 1 with a positive and significant standardized coefficient of +0.12 . Hypothesis 2 examined the impact of strong social ties on debt financing. The results of the study support hypothesis 2 with a negative and significant standardized coefficient of -0.13 . The results also support hypothesis 3 , which looked at the relationship between weak social ties and debt financing. As indicated in Table 2, weak social ties are positively and significantly related to debt financing with a standardized coefficient of +0.29 . Empirical results show that gender is not significantly related to debt financing (H4). Similarly, the results show that entrepreneur's age is not significantly related to debt financing (H5). Hypothesis 6 predicted 
that educational level would be positively related to debt financing. Empirical results support hypothesis 6 with a positive and significant standardized coefficient of +0.19 . Control variables were not found to be influential.

\section{Discussion and limitations}

\section{Discussion}

The purpose of this study was to analyze which entrepreneur's characteristics have a significant impact on debt financing of small manufacturing firms. The literature review revealed that there are still some entrepreneur's characteristics that are underexplored in connection with small firm financing, although it is widely recognized that small firms are the engines of economic development (Beck/Demirguc-Kunt 2006) and that small firm owners are an inseparable component of firm performance, growth, and financing activities (e.g., Coleman/Cohn 2000; Vos et al. 2007). In specific, there is no research on the influence of entrepreneurial self-efficacy on debt financing of small firms. In addition, the relationship between strong social ties and small firm debt financing has not been the focus of previous studies. With this paper, we contribute to a better understanding of the determinants of small firm debt financing by investigating the influence of entrepreneurial self-efficacy, strong and weak social ties, entrepreneur's age, gender, and educational level on debt financing of small firms.

The main contribution of the study arises from the empirical findings that entrepreneurial self-efficacy has a significant and positive influence on small firm debt financing. An entrepreneur who is confident in his or her abilities to succeed in entrepreneurial roles and tasks (Chen et al. 1998) uses more debt financing. A more self-efficacious entrepreneur believes in the accomplishment of stated goals and thus applies for debt financing to a greater extent than a less self-efficacious entrepreneur. From the supply-side point of view, lenders prefer lending financial sources to entrepreneurs with highly expressed entrepreneurial self-efficacy, since lenders will increase their confidence in entrepreneurs' capabilities for paying their liabilities back.

On the basis of the findings that higher entrepreneurial self-efficacy predicts access to more external financial sources, we suggest improving entrepreneurial self-efficacy for entrepreneurs who seek new funds. Entrepreneurial selfefficacy can be improved by learning and training (e.g., Lope Pihie/Bagheri 2011). Thus, we suggest increasing an entrepreneur's confidence in their abilities to perform entrepreneurial roles and tasks by attending training programs and educational seminars for entrepreneurs and by joining clubs or chambers through which entrepreneurs can get information, knowledge, experience, and support. In turn, such trainings can foster their confidence and belief in their entrepreneurial capacities. 
Nevertheless, entrepreneurial courses should be introduced in technical universities and high schools since it is there that many entrepreneurs are born. It should be noted that entrepreneurial trainings and lectures would be reasonable as early as in primary schools since it is within primary education that confidence in accomplishing stated goals and confidence in performing different tasks and roles is formed to a greater extent.

The results of the study reveal another important determinant of small firm debt financing - entrepreneur's strong social ties that refer to family members, relatives, and friends. No previous study has focused on the influence of strong social ties on debt financing of small firms. Our study confirmed the hypothesis that a larger network of strong ties has a negative effect on small firm debt financing. Larger the strong-tie network, lesser the need for debt financing, since strong ties can assist entrepreneurs in assembling necessary resources.

Research results also showed that entrepreneur's weak social ties have the largest influence on debt usage of small firms. Weak ties are significantly and positively related to small firm debt financing, which suggests that a larger network of acquaintances (e.g., advisors, banks, suppliers, lawyers, co-workers, club members, and other business partners) brings a wider and more heterogeneous range of information, access to financial resources, investment projects, and investors. Thus, in the process of accumulating financial resources, an entrepreneur should widen his or her social network of weak ties, which can result in more financial resources. The positive influence of weak social ties on small firm debt financing ascertained within this study is consistent with findings of prior studies that argued that networks are important for providing information about access to physical and financial resources (e.g., Johannisson 2000), broadening access to financial sources (e.g., Petersen/Rajan 1994, 1995), and facilitating access to resources possessed by other members of the network (e.g., Neergaard/Madsen 2004; Shaw/Conway 2000).

In addition, the results show that entrepreneur's educational level has a positive influence on small firm debt financing. This finding suggests that for less constrained access to external financing, entrepreneurs should pursue higher education. Our study also shows that contrary to some previous research (e.g., Ortiz-Molina/Penas 2008), entrepreneur's age has no influence on debt financing of small firms. Surprisingly, gender also has no significant impact on debt financing, although some scholars (e.g., Cavalluzzo et al. 2002; Coleman 2000) have shown that women entrepreneurs have more constrained access to external financing. Besides that, the results of the study are in line with some other Slovenian studies that indicate that there are no major gender differences in Slovenian firms (e.g., Bertoncelj/Kovac 2009).

We have demonstrated that entrepreneurial networks, self-efficacy, and educational level have significant effects on small firm debt financing. Since this is the first study that investigates the influence of entrepreneurial networks and 
self-efficacy on debt financing, future research is necessary for additional explanations of these relations.

\section{Limitations}

As with any research, several limitations should be noted. First, one important limitation of our study is that the entrepreneurial self-efficacy construct may be endogenous to the model (it may be determined by a set of factors that also determine the outcome). For example, although there is a small correlation between educational level and entrepreneurial self-efficacy, educational level may influence both entrepreneurial self-efficacy and debt financing. Failure to statistically correct for endogeneity can lead to biased coefficient estimates (Hamilton/Nickerson 2003).

One approach to address the issue of endogeneity is the use of instrumental variables (using predicted as opposed to observed values of a variable) and the 2SLS method. To use this method, it is necessary to identify at least one variable that is associated with the endogenous variable being predicted in the first stage of the equation (the instrumental variable) but is not associated with the outcome. None of the variables available in our data sets met this criterion. For these reasons, the potential problem of endogeneity was not addressed in this analysis; therefore, additional research is needed to identify potential instruments that could be used to predict entrepreneurial self-efficacy and to address the problem of endogeneity of this variable in modeling the determinants of debt financing.

Second, while the theory proposed the hypothesized causal directions, the crosssectional nature of this study cannot prove causation but can only support a set of hypothesized paths (Kline 2005). Therefore, we cannot eliminate the possibility of reverse causality. As Kline (2005) explained, to eliminate the possibility of reverse causality, longitudinal research is needed to determine the direction of causality of the relationships and to detect possible reciprocal causation. Third, this study used single-item measures for some of the independent variables. Although it is important to limit the number of items that respondents are asked to complete, we suggest that future studies employ multiple-item measures for these constructs and thus reduce the measurement error. Fourth, because the research sample included only manufacturing firms, research findings cannot be generalized to all firms. Future research should consider the extent to which the findings of this study apply to other sectors as well. 


\section{Acknowledgements}

The authors gratefully acknowledge the helpful comments of the two anonymous Reviewers and the Editor. The Centre of Excellence for Biosensors, Instrumentation and Process Control is an operation financed by the European Union, European Regional Development Fund and Republic of Slovenia, Ministry of Higher Education, Science and Technology.

Prof. Igor Prodan passed away just before the paper has been published. He was a great researcher and a great man. I am grateful to have had the opportunity to know him, to work with him and to learn from him. Thank you, Igor, for everything!

\section{References}

Aaronson, D./ Bostic, R. W./ Huck, P./ Townsend, R. (2004): Supplier relationships and small business use of trade credit, in: Journal of Urban Economics, 55, 1, 46-67.

Acs, Z. J./ Desai, S./ Klapper, L. (2008): What does "entrepreneurship" data really show?, in: Small Business Economics, 31, 3, 265-281.

Aldrich, H./ Rosen, B./ Woodward, W. (1987): The impact of social networks on business foundings and profit: a longitudinal study, in N. S. Churchill (Ed.), Frontiers of Entrepreneurship Research, 154-168.

Almus, M./ Nerlinger, E. A. (1999): Growth of new technology-based firms: which factors matter?, in: Small Business Economics, 13, 2, 141-154.

Avery, R. B./ Bostic, R. W./ Samolyk, K. A. (1998): The role of personal wealth in small business finance, in: Journal of Banking \& Finance, 22, 6-8, 1019-1061.

Ayyagari, M./ Beck, T./ Demirguc-Kunt, A. (2007): Small and medium enterprises across the globe, in: Small Business Economics, 29, 4, 415-434.

Bandura, A. (1977): Self-efficacy: Toward a unifying theory of behavioral change, in: Psychological Review, 84, 2, 191-215.

Bandura, A. (1997): Self-efficacy: the exercise of control. New York: JH. Freeman

Barton, S. L./ Matthews, C. H. (1989): Small firm financing: implications from a strategic management perspective, in: Journal of Small Business Management, 27, 1, 1-7.

Bates, T. (1990): Entrepreneur human capital inputs and small business longevity, in: Review of Economics \& Statistics, 72, 4, 551-559.

Baum, R. J./ Locke, E. A. (2004): The relationship of entrepreneurial traits, skill, and motivation to subsequent venture growth, in: Journal of Applied Psychology, 89, 4, 587-598.

Baycan-Levent, T./ Nijkamp, P. (2009): Characteristics of migrant entrepreneurship in Europe, in: Entrepreneurship \& Regional Development, 21, 4, 375-397.

Beck, T./ Demirguc-Kunt, A. (2006): Small and medium-size enterprises: access to finance as a growth constraint, in: Journal of Banking \& Finance, 30, 11, 2931-2943.

Beck, T./ Demirguc-Kunt, A./ Maksimovic, V. (2005): Financial and legal constraints to firm growth: does size matter?, in: The Journal of Finance, 60, 1, 137-177. 
Beck, T./ Demirguc-Kunt, A./ Martinez Peria, M. S. (2007): Reaching out: access to and use of banking services across countries, in: Journal of Financial Economics, 85, 1, 234266.

Bentler, P. M. (1988): Causal modeling via structural equation systems, in: J. R. Nesselroade / R. B. Cattell (Eds.), Handbook of multivariate experimental psychology. New York: Plenum Press, 317-335.

Bentler, P. M./ Bonett, D. G. (1980): Significance tests and goodness of fit in the analysis of covariance structures, in: Psychological Bulletin, 88, 3, 588-606.

Berger, A. N./ Udell, G. F. (1995): Relationship lending and lines of credit in small firm finance, in: Journal of Business, 68, 351-382.

Berger, A. N./ Udell, G. F. (1998): The economics of small business finance: the roles of private equity and debt markets in the financial growth cycle, in: Journal of Banking \& Finance, 22, 6-8, 613-673.

Berger, A. N./ Udell, G. F. (2006): A more complete conceptual framework for SME finance, in: Journal of Banking \& Finance, 30, 11, 2945-2966.

Bertoncelj, A./ Kovac, D. (2009): Gender difference in the conative componet of entrepreneurial orientation, in: Journal for East European Management Studies, 14, 4, 357-368.

Birley, S. (1985): The role of networks in the entrepreneurial process, in: Journal of Business Venturing, 1, 1, 107-117.

Boyd, N. G./ Vozikis, G. S. (1994): The influence of self-ffficacy on the development of entrepreneurial intentions and actions, in: Entrepreneurship: Theory \& Practice, 18, 4, 63-77.

Breckler, S. J. (1990): Applications of covariance structure modeling in psychology, in: Psychological Bulletin, 107, 2, 260-273.

Bruderl, J./ Preisendorfer, P. (1998): Network support and the success of newly founded businesses, in: Small Business Economics, 10, 3, 213.

Burt, R. S. (2001): Structural holes versus network closure as social capital, in N. Lin/ K. S. Cook/R. S. Burt (Eds.), Social capital: theory and research, New York: Aldine de Gruyter, 31-56.

Butler, J. E./ Hansen, G. S. (1991): Network evolution, entrepreneurial success, and regional development in: Entrepreneurship \& Regional Development, 3, 1, 1-16.

Byrne, B. M. (2006): Structural equation modeling with EQS : basic concepts, applications, and programming (2nd ed.). Mahwah (N.J.): Lawrence Erlbaum Associates.

Caputo, R. K./ Dolinsky, A. (1998): Women's Choice to Pursue Self- Employment: The Role of Financial and Human Capital of Household Members, in: Journal of Small Business Management, 36, 3, 8-17.

Carter, R. B./ Van Auken, H. (2005): Bootstrap financing and owners' perceptions of their business constraints and opportunities, in: Entrepreneurship \& Regional Development, $17,2,129-144$.

Cassar, G. (2004): The financing of business start-ups, in: Journal of Business Venturing, 19, 2, 261-283. 
Cavalluzzo, K. S./ Cavalluzzo, L. C. (1998): Market structure and discrimination: the case of small businesses, in: Journal of Money, Credit \& Banking, 30, 4, 771-792.

Cavalluzzo, K. S./ Cavalluzzo, L. C./ Wolken, J. D. (2002): Competition, small business financing, and discrimination: evidence from a new survey, in: Journal of Business, $75,4,641-679$.

Chaganti, R. (1986): Management in women-owned enterprises, in: Journal of Small Business Management, 24, 4, 18-29.

Chaganti, R./ Decarolis, D./ Deeds, D. (1995): Predictors of Capital Structure in Small Ventures, in: Entrepreneurship: Theory \& Practice, 20, 2, 7.

Chen, C. C./ Greene, P. G./ Crick, A. (1998): Does entrepreneurial self-efficacy distinguish entrepreneurs from managers?, in: Journal of Business Venturing, 13, 4, 295-316.

Cole, R. A. (2008): Who needs credit and who gets credit? Evidence from the surveys of small business finances. Washington: World Bank.

Coleman, S. (2000): Access to capital and terms of credit: a comparison of men- and womenowned small businesses, in: Journal of Small Business Management, 38, 3, 37-52.

Coleman, S. (2007): Women-owned firms and growth, in: Journal of Business and Entrepreneurship, 19, 2, 31-44.

Coleman, S./ Cohn, R. (2000): Small firms' use of financial leverage: evidence from the 1993 national survey of small business finances, in: Journal of Business and Entrepreneurship, 12, 3, 87-130.

Cornett, A. P. (2009): Aims and strategies in regional innovation and growth policy: A Danish perspective, in: Entrepreneurship \& Regional Development, 21, 4, 399-420.

Darrough, M. N./ Stoughton, N. M. (1986): Moral Hazard and Adverse Selection: The Question of Financial Structure, in: Journal of Finance, 41, 2, 501-513.

Dillman, D. A. (2000): Mail and internet surveys: the tailored design method (2nd edition ed.). New York: Chichester: John Wiley.

Flannery, M. J. (1986): Asymmetric Information and Risky Debt Maturity Choice, in: Journal of Finance, 41, 1, 19-37.

Gist, M. E. (1987): Self-Efficacy: Implications for Organizational Behavior and Human Resource Management, in: Academy of Management Review, 12, 3, 472-485.

Granovetter, M. S. (1973): The strength of weak ties, in: American Journal of Sociology, 78, $6,1360-1380$.

Greve, A. (1995). Networks and entrepreneurship - an analysis of social relations, occupational background, and use of contacts during the establishment process. Scandinavian Journal of Management 11, 1-24.

Hair, J. F./ Anderson, R. E./ Tatham, R. L./ Black, W. C. (1998): Multivariate data analysis (5th ed.). Upper Saddle River (N.J.): Prentice-Hall.

Hair, J. F./ Black, W. C./ Babin, B. J./ Anderson, R. E. (2010): Multivariate data analysis (5th ed.). Upper Saddle River (N.J.): Prentice-Hall.

Hallberg, K. (2000): A market-oriented strategy for small and medium scale enterprises. Washington: International Finance Corporation. 
Hamilton, B. H./ Nickerson, J. A. (2003): Correcting for endogeneity in strategic management research, in: Strategic organization, 1, 1, 51-78.

Heyman, D./ Deloof, M./ Ooghe, H. (2008): The financial structure of private held Belgian firms, in: Small Business Economics, 30, 3, 301-313.

Hmieleski, K. M./ Corbett, A. C. (2008): The contrasting interaction effects of improvisational behavior with entrepreneurial self-efficacy on new venture performance and entrepreneur work satisfaction, in: Journal of Business Venturing, $23,482-496$.

Hughes, A. (1996): Finance for SMEs. What needs to change?, in R. Cressy/ B. Gandemo/C. Olofsson (Eds.), Financing SMEs-a comparative perspective, Stockholm: NUTEK.

Hutchinson, R. W. (1995): The capital structure and investment decisions of the small ownermanaged firm: some exploratory issues, in: Small Business Economics, 7, 3, 231-239.

Jo, H./ Lee, J. (1996): The relationship between an entrepreneur's background and performance in a new venture, in: Technovation, 16, 4, 161-171.

Johannisson, B. (2000): Networking and entrepreneurial growth, in D. Sexton/H. Landstrom (Eds.), Handbook of Entrepreneurship, Oxford: Blackwell, 368- 386.

Johnson, P./ Conway, C./ Kattuman, P. (1999): Small business growth in the short run, in: Small Business Economics, 12, 2, 103-112.

Kline, R. B. (2005): Principles and practice of structural equation modeling (2nd edition ed.). New York: Guilford Press.

Krueger, N. (1993): The impact of prior entrepreneurial exposure on perceptions of new venture feasibility and desirability, in: Entrepreneurship: Theory \& Practice, 18, 1, 521.

Krueger, N. F./ Reilly, M. D./ Carsrud, A. L. (2000): Competing models of entrepreneurial intentions, in: Journal of Business Venturing, 15, 5-6, 411-432.

Le, N. T. B./ Nguyen, T. V. (2009): The Impact of Networking on Bank Financing: The Case of Small and Medium-Sized Enterprises in Vietnam, in: Entrepreneurship: Theory \& Practice, 33, 4, 867-887.

Liao, H.-H./ Chen, T.-K./ Lu, C.-W. (2009): Bank credit risk and structural credit models: Agency and information asymmetry perspectives, in: Journal of Banking \& Finance, $33,8,1520-1530$.

Lope Pihie, Z. A./ Bagheri, A. (2011): Malay Secondary School Students' Entrepreneurial Attitude Orientation and Entrepreneurial Self-efficacy: A Descriptive Study, in: Journal of Applied Sciences, 11, 2, 316-322.

MacMillan, I. C./ Siegel, R./ Narasimha, P. N. S. (1985): Criteria used by venture capitalists to evaluate new venture proposals, in: Journal of Business Venturing, 1, 1, 119-128.

McGibbon, S. C./ Moutray, C. (2009): The small business economy. Washington, DC: U.S. Small Business Administration.

McMahon, R. G. P./ Stanger, A. M. J. (1995): Understanding the Small Enterprise Financial Objective Function, in: Entrepreneurship: Theory \& Practice, 19, 4, 21-39.

Mester, L. J. (1997): What's the point of credit scoring?, in: Federal Reserve Bank of Philadelphia Business Review, 9/10, 3-16. 
Michaelas, N./ Chittenden, F./ Poutziouris, P. (1999): Financial policy and capital structure choice in U.K. SMEs: empirical evidence from company panel data, in: Small Business Economics, 12, 2, 113-130.

Mone, M. A./ Baker, D. D. (1995): Predictive validity and time dependency of self-efficacy, self-esteem, personal goals, and, in: Educational \& Psychological Measurement, 55, 5, 716.

Mone, M. A./ McKinley, W./ Barker III, V. L. (1998): Organizational decline and innovation: a contingency framework, in: Academy of Management Review, 23, 1, 115-132.

Morris, M. H./ Miyasaki, N. N./ Watters, C. E./ Coombes, S. M. (2006): The Dilemma of Growth: Understanding Venture Size Choices of Women Entrepreneurs, in: Journal of Small Business Management, 44, 2, 221-244.

Myers, S. C. (1984): The capital structure puzzle, in: The Journal of Finance, 39, 3, 575-592.

Myers, S. C./ Majluf, N. S. (1984): Corporate financing and investment decisions when firms have information that investors do not have, in: The Journal of Financial Economics, $13,2,187-221$

Neergaard, H./ Madsen, H. (2004): Knowledge intensive entrepreneurship in a social capital perspective, in: Journal of Enterprising Culture, 12, 2, 105-125.

Neubauer, F./ Lank, A. G. (1998): The Family Business: Its Governance for Sustainability. London: Macmillan Press.

Olson, S. F./ Currie, H. M. (1992): Female enterpreneurs: personal value systems and business strategies in a male-dominated industry, in: Journal of Small Business Management, 30, 1, 49-57.

Ortiz-Molina, H./ Penas, M. F. (2008): Lending to small businesses: the role of loan maturity in addressing information problems, in: Small Business Economics, 30, 4, 361-383.

Ozgen, E./ Baron, R. A. (2007): Social sources of information in opportunity recognition: effects of mentors, industry networks, and professional forums, in: Journal of Business Venturing, 22, 2, 174-192.

Petersen, M. A./ Rajan, R. G. (1994): The benefits of lending relationships: evidence from small business data, in: Journal of Finance, 49, 1, 3-37.

Petersen, M. A./ Rajan, R. G. (1995): The effect of credit market competition on lending relationships, in: Quarterly Journal of Economics, 110, 2, 407-443.

Petersen, M. A./ Rajan, R. G. (2002): Does distance still matter? The information revolution in small business lending, in: Journal of Finance, 57, 6, 2533-2570.

Prodan, I. (2007): Technological entrepreneurship: technology transfer from academia to new firms: University of Ljubljana.

Prodan, I./ Drnovsek, M. (2010): Conceptualizing academic-entrepreneurial intentions: An empirical test, in: Technovation, 30, 5-6, 332-347.

Roberts, E. B. (1991): Entrepreneurs in high technology: lessons from MIT and beyond. New York: Oxford University Press.

Romano, C. A./ Tanewski, G. A./ Smyrnios, K. X. (2001): Capital structure decision making: A model for family business, in: Journal of Business Venturing, 16, 3, 285-310. 
Scherer, R. F./ Adams, J. S./ Carley, S. S./Wiebe, F. A. (1989): Role model performance effects on development of entrepreneurial career preference, in: Entrepreneurship: Theory \& Practice, 13, 3, 53-71.

Scherr, F. C./ Sugrue, T. F./ Ward, J. B. (1993): Financing the small firm startup: determinants for debt use, in: Journal of small business finance, 3, 1, 17-36.

Sharma, S./ Durvasula, S./ Dillon, W. R. (1989): Some results on the behavior of alternate covariance structure estimation procedures in the presence of non-normal data, in: Journal of Marketing Research, 26, 2, 214-221.

Sharpe, S. A. (1990): Asymmetric Information, Bank Lending, and Implicit Contracts: A Stylized Model of Customer Relationships, in: Journal of Finance, 45, 4, 1069-1087.

Shaw, E./ Conway, S. (2000): Networking and the Small Firm, in S. Carter/D. Jones-Evans (Eds.), Enterprise and Small Business, Harlow: Prentiss Hall, 305-322.

Shook, C. L./ Ketchen, D. J./ Hult, G. T. M./ Kacmar, K. M. (2004): An assessment of the use of structural equation modeling in strategic management research, in: Strategic Management Journal, 25, 4, 397-404.

Singh, R. P. (1998): Entrepreneurial opportunity recognition through social networks. Illinois: University of Illinois at Chicago.

Stiglitz, J. E./ Weiss, A. (1981): Credit rationing in markets with imperfect information, in: American Economic Review, 71, 3, 393-410.

Storey, D. J. (1994a): Understanding the Small Business Sector. London: Rutledge.

Storey, D. J. (1994b): The role of legal status in influencing bank financing and new firm growth, in: Applied Economics, 26, 2, 129-136.

Torre, A. d. 1./ Martinez Peria, M. S./ Schmukler, S. L. (2008): Bank involvement with SMEs: beyond relationship lending. Washington: International Financial Corporation.

Valliere, D./ Peterson, R. (2009): Entrepreneurship and economic growth: Evidence from emerging and developed countries, in: Entrepreneurship and Regional Development, 21, 5-6, 459-480.

Van de Ven, A. H./ Hudson, R./ Schroeder, D. M. (1984): Designing new business startups: entrepreneurial, organizational and ecological considerations, in: Journal of Management Science, 10, 1, 87-107.

Van der Wijst, D. (1989): Financial structure in small business. Theory, tests and applications. Berlin: Springer-Verlag.

Vos, E./ Yeh, A. J.-Y./ Carter, S./ Tagg, S. (2007): The happy story of small business financing, in: Journal of Banking \& Finance, 31, 9, 2648-2672.

Waldinger, R./ Aldrich, H./ Ward, R. (1990): Ethnic Entrepreneurs: Immigrant Business in Industrial Societies. Newbury Park, CA.

Wilbon, A. D. (2000): Executive technology education and firm performance, in: Technology Management: Strategies and Applications, 5, 1, 103-109.

Wood, R./ Bandura, A. (1989): Social cognitive theory of organizational management, in: The Academy of Management Review, 14, 3, 361-384. 
Wu, Z./ Chua, J. H./ Chrisman, J. J. (2007): Effects of family ownership and management on small business equity financing, in: Journal of Business Venturing, 22, 6, 875-895.

Zhao, H./ Seibert, S. E./ Hills, G. E. (2005): The mediating role of self-efficacy in the development of entrepreneurial intentions, in: Journal of Applied Psychology, 90, 6, 1265-1272. 